Jawad Kadir

Department of Politics, Philosophy and Religion (PPR)

Lancaster University,

Bailrigg

Lancashire, United Kingdom

LA1 4YW

Office:

B-64, County South

County College,

Lancaster University

LA1 4YD

+44 (0)1524594290

$+447405230181$

Email:

j.kadir@lancaster.ac.uk

jawadkadir07@gmail.com 


\title{
PERCEIVING THE ENEMY DIFFERENTLY: A PSYCHO-CULTURAL ANALYSIS OF PAKISTAN-INDIA CONFLICT
}

\begin{abstract}
By using an interdisciplinary approach, this article seeks to examine Pakistan-India partition and their ongoing rivalry which is a permanent threat to South Asian regional security. This article analyses Pakistan-India conflict through a fresh psycho-cultural framework to explain both states' endless competitive urge to outpace each other. I will describe the attributes of the indigenous 'culture of conflict' in both countries and use them as an 'analogy'. This article develops a conflict theory to explain the rationale behind such an emotion-laden rivalry between two nations. The conflict theory presented in this article (which can be termed as Sharike-Bazi Culture of Conflict) explains that peoples' conflict behaviours in Pakistan (and India) are rooted in their earliest socialization within primary kinship institutions.

In Pakistan (and India), the indigenous 'culture of conflict' emanates from the segmentation of the most pervasive and influential institutions; the kinship institutions. The moralities of conflict behaviour learned within these institutions are extrapolated to every other institution in the outside world. Therefore, psychologically, the indigenous 'culture of conflict' creates certain moral views effecting the conflict behaviour of people as well as policy makers. It provides them with cultural moralities to pursue this zero-sum interstate conflict.
\end{abstract}

Key Words: India-Pakistan, Culture of Conflict, Psycho-cultural analysis, conflict behaviour, Batwara, Sharike-Bazi Conflict Theory. 


\section{Introduction}

The India-Pakistan conflict is said to be simultaneously over territory, national identity, and power position in the region (Paul, 2005, pp. 3-8). The obsession with India is a key factor in determining Pakistan's foreign and domestic policies, which 'start' and 'end' at Indian borders (Cohen, 2013). India and Pakistan have been locked in an open hostility since their inception. They have fought three conventional wars and several armed conflicts, such as Kargil. They regularly display their nuclear capability to outpace each other, which is always a question mark on South Asian/Asian security.

A large number of nation-states came into being as a result of intergroup conflicts on political, ideological, religious, territorial, or ethnic grounds, but many of them have resolved their mutual conflicts or at least managed them to move forward (Bar-Tal, 2013, pp. 1-8). However, India and Pakistan have been psychologically obsessed with their conflicts since their partition in 1947. It can be explained, in part, as a result of conflicting versions of partition history taught in both countries to demonize the other (Aziz, 1993; Gautier, 1996). But people-to-people limited interaction after partition can also be regarded as an additional factor for their continuing obsession with each other. India-Pakistan conflict seems to possess minimum material value when compared to the huge emotional energies invested by both nations. From a Pakistani perspective, this paper seeks to examine the reasons behind both nations' obsession with each other which do not let them forget past events.

Numerous theories have tried to explain the causal factors for the ongoing rivalry between Pakistan and India. Realism and neo-Realism focus on 'fear' factor for Pakistan's pursuance of 'power' for its survival (Rizvi, 1993, pp. 1-17). The rational models present logical reason that a powerful and hostile neighbour can compel a (weak) state like Pakistan to attain the capacity for defence. However, I argue, that such explanations are inadequate to explain India- 
Pakistan conflict dynamics to its entirety. They can't explain a firm Pakistani 'faith' that they can defeat a country ten times larger than their own. My conjecture is that such extra-aggressive and "irrational" conflict behaviour should also be analysed from a psychological perspective.

In contrast to existing academic literature which holds an international system of anarchy and material interests responsible for Pakistan-India rivalry, this article examines the existing landscape of conflict from a different psycho-cultural framework to understand Pakistan's behaviour in its conflict dynamics with India. This paper examines Pakistan-India conflict by using the attributes of their indigenous 'culture of conflict', which emanates from the segmentation of the most pervasive kinship institutions of 'joint family' and 'lineage' in both countries. Despite emphasizing much upon the role of 'institutions', the political analysts have often ignored the most initial, most salient, most emotionally powerful, and the most functional "kinship institutions" in both countries while examining their conflict.

This inquiry will examine how people's cultural behaviour of conflict dealing effects their behaviour in a national domain and impacts on the macro institutions of the state. As people in the subcontinent tend to transpose the psychological moral structure of their kinship institutions to every other institution in the outside world (Kakar and Kakar, 2009, Lyon, 2004, Lieven, 2012); therefore, the conflict behaviour learned within these kinship institutions is also extrapolated to the other larger socio-political institutions. This article proposes that the Pakistan-India conflict is a mirror image of their indigenous 'cultures of conflict' in the subcontinent. The indigenous 'culture of conflict', which can be termed as "Sharike-Bazi" explains the conflict dynamics of intimate rivalries between kin groups (patrilineal cousins). Such a rivalry is always aimed at competing and defeating the other party even at the cost of one's own destruction; a basic element of Pakistan-India rivalry. 
This article explains how Pakistan-India rivalry became so intense and emotionally driven, by analysing the cultural underpinnings of their psychological obsession with each other. This article will analyse peoples' indigenous conflict behaviour (especially from the Pakistani side) and its presence in interstate relations. I argue that both nations' obsession with each other appears to owe more to their cultural sameness than their differences. Their historical, geographical, racial and cultural ties do not allow them to ignore each other (Buzan, 1991, p. 78). This article, therefore, presents a fresh psycho-cultural perspective to understand the motivation behind the competitive urge that drives the Pakistani public, leaders, and army officers to defy India's obvious numeric, economic and military supremacy, and to do so with such intensity.

The psycho-cultural approach builds its theoretical framework on the notion that the earliest socialization of people within primary kinship institutions is central in developing their worldviews. This approach seeks to establish a causal link between peoples' behaviour to that of the broader national behaviour. It explains people and their society through a dynamic analysis of the formation of their personalities within the cultural milieu (Stoddart \& Hession, 1951). It recognizes both emotional and behavioural conditioning and seeks to relate these acquired tendencies to the patterns of people's behaviour as an adult in his family, community, social, economic, and political life.

The rationale behind explaining Pakistan-India rivalry through the psycho-dynamics of 'indigenous culture of conflict' lies in the argument that it emanates from the segmentation of kinship institutions; the most emotional, pervasive and authoritative 'institutions' for people in both Pakistan and India (Lyon, 2004, Lieven, 2012, Kakar and Kakar, 2009). Secondly, there exists a cultural and psychological proximity between both nations for sharing a syncretized society for centuries in the past. Despite having enormous ethnic diversity and religious differences, people in the subcontinent not only share a cultural gene pool and identical kinship 
structures (Kakar, 2006), but also similar conflict behaviour. This article also examines how both nations, despite being culturally so similar, are engaged in such an emotionally charged rivalry.

\section{Why not Existing Theoretical Models?}

There is dearth of scholarly literature explaining the logical reasons behind the psychosis of 'hatred' and competition between Pakistan and India. On the face of it, there are two contradictory schools of thought explaining the reasons for this hostility: one finds faults with Pakistan's revisionist, expansionist and greedy agenda for spreading its territorial and ideological expansionism (Fair, 2014, Ganguly, 2016). The other school holds Indian hegemonic designs responsible for Pakistan's security seeking behaviour (Razvi, 1982, Ahmed, 2013). It is also argued by scholars that Pakistan is a 'Garrison' (Siddiqa, 2007), and 'warrior' state (Paul, 2014). These scholars are in intellectual agreement that military regimes in Pakistan pursue their own institutional interests and regard permanent enmity with India as raison d'etre for their existence.

Fair (2014) has aptly remarked that Pakistan will keep on competing with India even at the cost of its own destruction. Pakistani military's paranoia with gaining recognition as equal to India is unending despite a widening gap between their national capabilities. Pakistan's military rejects Indian regional ascendency "by seeing victory as the ability to continue fighting' to the end" (p.7).

I argue that Pakistan's ambitious behaviour towards India can also be explained as an outcome of interactive process between masses and political elite. Regardless of civil or military regimes, since day one Pakistan has always pursued policies that must be diametrically opposite to Indian policies. The increasing role of military in state's politics can also be 
explained by the popular 'desire' for competing/defeating India at any cost, which can be regarded as one of the driving forces behind Pakistan's adventurous policies.

Furthermore, the military can be blamed for thwarting peace efforts attempted by Pakistani politicians. However, the army's claim over territorial/ideological guardianship of the state is supported by a public majority for being the only "powerful" institution that can compete with India. Both political and military elite play upon popular sentiments against India to earn legitimacy. In fact, it is politicians not men-in-uniform, who gain more by anti-Indian rhetoric (Faruqi, 2000). This paper examines the cultural foundations of such combative behaviour towards India.

India-Pakistan partition and conflict have mostly been analysed by theological cum ideological models which assume 'Hindu' and 'Muslim' as fixed - rather opposing political categories. A school of thought says that both communities always had distinct identities, having dissimilar religion and cultures (Robinson, 1974; Savarkar, 1969; Sayeed, 1960). Indeed, the 'instrumental' role of religion cannot be denied (Brass, 1974) while explaining India-Pakistan rivalry and can be termed as the most powerful divider between the two nations. Even the Pakistani nuclear bomb was dubbed as "Islamic bomb" against a "Hindu bomb" (Bhutto, 1969, p. 151). But, the need of this "Islamic" bomb was felt against the widening gap between Pakistan-India military capabilities, especially after the separation of the eastern arm (now Bangladesh) purely on ethno-linguistic and political grounds. Interestingly, 'Hindu' India helped the cause of 'Muslim' Bengalis against their own west Pakistani Muslim brethren (Malik, 1993).

I argue that the religion, undoubtedly, was/is an important vehicle by which antipathies were/are constructed between both groups, but it must not be regarded as the only factor behind the creation of Pakistan and ongoing hostility between both nations. The subcontinent has 
always been a multi-religious region, which has always absorbed people from different faiths according to its indigenous principles of caste and cultural hierarchy. Moreover, both religions are severely fragmented along caste and sectarian lines in the subcontinent. The "religion" focus also raises serious questions as to why leading religious parties had opposed the idea of 'Muslim' Pakistan presented by Jinnah (Talbot, 2003; Syed, 1982, p. 35).

The above interpretation is opposed by another school of thought which draws a symbiotic picture of Hindu-Muslim syncretic culture and religious harmony in pre-colonial and early colonial period. They blame the British, who made communalism grow between both sistercommunities to pursue their colonist agenda (Pandey, 1990). I argue that mentioning the syncretic part of culture only, is also incomplete. This version presents an ideal melting pot model for distinct cultural identities. In fact, South Asia has been a salad bowl of cultures, not a melting pot (Nandy, Trivedy, Mayaram \& Yagnik, 1995). In a salad, the different ingredients retain their distinctiveness as different religious groups managed to do so for centuries in the subcontinent

This article argues that despite having religious and ethnic differences, people in the subcontinent possess similar conflict behaviour due to their identical kinship structures. Both states had to adopt different ideologies otherwise the reason to part ways could not be justified. Pakistan had no option other than to move along religion's trajectory, because religion was the dissimilar element between two communities that were otherwise more or less homogenous. In fact, Pakistan could opt for a secular path, had India adopted 'Hinduism' as its starting track. It implies that from the Pakistani perspective, the focal point is not 'religion', but the 'desire' of people to prove the 'other' as 'different' and 'wrong'. 


\section{Methodology and Organizing Schema}

Primarily, this paper uses a method of analogy-making; analogies are used to relate known to unknown experiences, to uncover other similarities once some basic resemblances are noted (O'Conner, 1971). Analogy is a form of scientific method that uses one set of behaviour to analyse and explain the behaviour of other phenomena (Morlidge \& Player, 2010, p. 287). This methodology will help me to compare Pakistani family level conflict behaviour to that of Pakistani national behaviour against India. The analogy-method follows Aristotle's saying that 'to be a master of metaphor is a sign of "genius", since a good metaphor implies an eye for resemblance' (Lancaster, 2015). I will also use discourse analysis method to analyse the primary and secondary data, providing empirical evidence to evaluate the main hypothesis that if and how this analogous model is relevant to understand Pakistan-India conflict.

The first section explains the psycho-cultural approach in general, and, psycho-cultural interpretive theory of conflict (Ross, 1995); a fusion of psycho-analytic and psycho-social theories. The second section uses ethnographic data to explain the indigenous culture of conflict model "Sharike-Bazi" in Pakistan (and India). The secondary data has also been provided to substantiate the applicability of this model as analogy for Pakistan-India conflict. By using discourse analysis as a method, the third section explores the psycho-genesis of the India-Pakistan conflict and presents it as a mirror image of their traditional cultures of conflict. The fourth section situates conflict theory developed in this paper along with mainstream interstate theories i.e., realism and constructivism. The final section concludes how psychosis of hatred between both nations has certain cultural content. 


\section{Theoretical Approach: Defining Units of Analysis}

The institutional role of government, army and religion has been much analysed by theorists when explaining Pakistan-India conflict, however, the most enduring and influential institutions in this region have been grossly ignored. Despite enormous ethnic and religious diversity, South Asian people share common kinship institutions: the extended family group joined by marriage, which is called Khandan in Pakistan and Pariwar in India; or, the lineage group with common descendants, known as Biradari in Pakistan and Jati in India. ${ }^{\text {a }}$ The "indigenous culture of conflict" in the subcontinent also emanates from these most stable and dominant social institutions when they undergo segmentation. This article examines these primary kinship institutions, and indigenous 'culture of conflict' as units of analysis to study Pakistan-India rivalry.

The main argument of this study is that the moralities of a 'culture of conflict' associated within kinship institutions are also transposed into other institutions of society, and, hence state, which effect policy making. It is not to say that macro socio-economic or politico-religious variables are/were not relevant behind the animosity between both nations, but the emphasis is on the argument of how the conflict behaviour shaped within kinship institutions creates certain moral views which effect peoples' conflict behaviour in wider domains of society and nation.

In the following section, I will use a qualitative research paradigm as a prelude to develop my own theoretical model for analysing Pakistan-India conflict i.e. the Sharike-Bazi model. I will draw upon Psycho-Cultural Interpretive theory of conflict presented by Ross (1995) to explain the general characteristics of 'culture of conflict' in Pakistan. Ross (1995) explains how conflict is always a cultural behaviour and how people develop conflict behaviour in early socialization within their immediate social institutions e.g. family and extended family networks. 
A clear definition of conflict that can be applied widely across cultural settings is: "conflict means perceived divergence of interest, or a belief that parties' current aspirations cannot be achieved simultaneously" (Rubin, Pruitt, and Kim, 1994, p. 4). It implies that considering the perceptual part of the conflict is equally important, which in turn, is mostly shaped by culture. Culture shapes peoples' perception and behaviour about conflict (Ross, 1993, p. 21). The 'Culture of Conflict' is "society's specific norms, practices, and institutions associated with conflict' (Ross, 1993, p. 183). In short, a 'culture of conflict' is a prevailing worldview in any particular society which is used to handle the conflict.

Different institutions can play important roles in peoples' lives to develop certain conflict behaviours. The psycho-cultural analysis of conflict focuses on a group's psycho-cultural dispositions or culturally shared response tendencies toward conflict; learned through primary social institutions (Ross, 1995). These dispositions, in turn, are crucial in generating an interpretive mechanism for people to perceive the conflict, and deal with it. Therefore, psychologically, people frame every conflict around them, according to the cultural norms they had learned from their early socialization. For example, abusing someone's elder brother might have different responses in different cultures. Such a wrong-doer might be murdered in some traditional society, such as Punjab-Pakistan.

At the core of psycho-cultural interpretation theory is the notion that the inner worlds of people in a culture are socially constructed, rooted in the earliest social relationships. An individual's internal world contains primordial models of human interaction involving nurturance, conflict, authority, power and community (Ross, 1995). The theory gives a central role to culturally rooted social and psychological processes which produce dispositions - shared images, perceptions of the external world, and motives for individual and group behaviour. Dispositions formed in early social relationships and internalized images of the world established in family contexts provide a template for later relations involving larger social aggregates, such as those 
involving ethnic identities and are called upon later at the time of high-anxiety events, such as communal conflicts (Ross, 1995).

Culture always remains a factor in conflict, whether it plays a central role or influences it quietly. LeBaron (2003) adds that for any conflict that touches us where it matters (where we make meaning and hold our identities) there is always a cultural component. Intractable conflicts like the Israeli-Palestinian conflict or the India-Pakistan conflict are not just about territorial, boundary, and sovereignty issues - they are also about acknowledgment, representation, and legitimization of different identities and ways of living, being, and making meaning (LeBaron \& Venashri, 2006, p. 16). Culture is inextricable from conflict, though it does not cause it. When differences surface in families, organizations, or communities, culture is always present, shaping perceptions, attitudes, behaviours and outcomes. Therefore, studying societies' cultural methods of conflict dealing can be a useful way to understand their perception about conflict in wider domains.

People map their 'idealized' family models onto the societal domain and these models produce certain moral systems which effect peoples' political behaviour for how the nation should be governed (Lakoff, 1996). I have argued that conflict dynamics and behaviour related to these "idealized" family models are also mapped onto wider domains, such as society and nation. Therefore, I will use conflict dynamics of joint/extended family - an idealized family model in Pakistan - to analyse Pakistani society's overall conflict behaviour. The argument is also supported by Ross (1995) that people react in conflict situations in wider domains according to specific dispositions invoked in such situations; rooted in early experience. The analogymaking method will help to compare family level conflict behaviour to that of Pakistani conflict behaviour as a nation. 
The family and lineage are the most important institutions that constitute the primary building blocks of Indian identity (Kakar, 2006). For Pakistanis, all political or religious ideologies are temporary, but kinship group identity is the most enduring one (Lieven, 2012). Therefore, no 'ism' is more dominating than 'family-ism' in both societies. From the ranks of family, people learn to understand the differences between right and wrong. People learn from their family how to react in conflicts with other members of the society; and the states are nothing but the thermostat of their societies' spirit as Lebow (2008) has noted.

Pakistanis tend to impose some kind of kin relation to all individuals that they interact with (Lyon, 2004, p. 97). The behaviours learned within kinship institutions not only influences the mental programming of people in Pakistan but also effects the structure and functioning of a number of institutions other than the family. South Asian societies have an integrative and hierarchical relationship between individual and 'collectivity', which are mapped onto other societal functions and institutions (Channabasavanna \& Bhatti, 1982). The rules learnt by people through these powerful kinship organizations are observed even in today's high-tech modern organizations, not to mention political institutions (Kakar \& Kakar, 2009). It can be inferred, therefore, that conflict behaviour learned within these institutions is also transposed and reflected in the other institutions responsible for policy making (especially in Pakistan).

A central tenet of psycho-cultural approach is to compare the complexities of national behaviour, character and culture with the behaviour, character and culture of individuals. This approach attempts to understand the integration of institutions in a culture in terms of the basic personality-forming institutions and their impact on the other institutions of society (Stoddart \& Hession, 1951). It deals with the special personality drives and emotional characteristics in any society, which these micro primary institutions develop in its people, which are later reflected in other macro institutions. The behaviour of people is shaped by their culture in ways 
far below the level of consciousness, and, culture and mind cannot be distinguished from each other (Cole, 1998). Put it simply, human psyche and culture are inseparable and co-construct each other. This paper examines culturally conditioned habits, of conflict perception and behaviour which are somehow unconscious, because they shape conflict behaviour in both societies which then reflects in the larger picture of conflict dynamics between two states.

\section{Sharike-Bazi Culture of Conflict - An Analogy for Pakistan-India Conflict}

In this section, the indigenous Pakistani culture of conflict 'Sharike-Bazi' is explained by analysing the existing ethnographic literature. The dynamics of this culture of conflict has also been tested as an 'analogy' against Pakistan's conflict behaviour towards India. It is imperative to mention here that the scope of this paper is not to present empirical evidence in detail, but to present indigenous 'culture of conflict' as a theoretical model for further investigation. However, empirical evidence is provided, where necessary, to justify the workability of this model.

The indigenous Sharike-Bazi conflict model highlights the demands of separation (Batwara) by one sibling from the 'other' but denied a fair share. The 'wronged' brother then becomes extra competitive to right the wrong done to him. The 'other' brother, on the other hand, always tries to undo the new identity of his departing brother. I propose that Pakistan perceives herself as the 'wronged' brother in this dyad; revengeful against the 'other' brother 'India' over the unfair distribution of assets, and uncomfortable with the dominance of the 'other' estranged brother - now a sworn enemy.

In the subcontinent, cases where brothers/cousins live in peace after dividing the property are rare, because the division itself is an outcome of their inability to continue living together. Disputants blame the 'other' both for being the reason and beneficiary of the partition. 
Similarly, Pakistan developed grievances over unfair division of land (especially Kashmir), and other joint assets (military equipment, industrial complexes, bank reserves etc.) inherited from British India (Faruqui, 2003, p. 41). India developed its own version that the Muslim League's demand for dividing India was unfair, which resulted in the amputation of mother India and the disunion of the Indian family.

'Sharike-Bazi' is a term used in Punjab-Pakistan for the culture of conflict. The Sharike-Bazi culture of conflict is also observed in the other provinces of Pakistan (and India) with different names, for example, Tarbur in Pashtun areas of Pakistan (Barth, 1959). The selection of the Punjab province is crucial because it is the most populous and authoritative province in Pakistan. It enjoys an uncontested role in policy making thanks to its overwhelming representation in both parliament and military establishment (Lieven, 2012, p. 263). Secondly, the Punjab is one of only three provinces which were divided at the time of partition (both India and Pakistan have Punjab provinces). Thirdly, Punjab experienced the highest magnitude of bloody riots in 1947.

In subcontinent India and Pakistan, the real or step-brothers and their children live jointly and share the inherited resources. They live either under a same roof or in different houses. Usually, the Batwara (literally meaning the division of ancestral property) takes place when either of the brothers (or a cousin) feels that he is not being given a proper share or respect in the jointfamily. He, therefore, demands partition; the division of resources. Such demand, itself, is a starting point of feud between brothers or cousins, because it is considered against the cultural norms of integrated families.

The partition (Batwara) creates conflict, bitterness and hostility if the distribution is not settled fairly between both parties. Usually, the departing brother perceives that he is being wronged and cheated over resource distribution. The other party, on the other hand, blames the departing 
party for sowing the seeds of disunity. This bitterness transmutes to the future generations of paternal cousins who form a sub-lineage group, which is called Sharika in Punjabi language. These warring paternal groups are then engaged in Sharika rivalry for generations; the cousins are named as 'Shariks', and this rivalry can be termed as 'Sharike-Bazi'. Viewed this way, Pakistan and India can be termed as 'Sharik' states (cousin-enemy states), who have been engaged in an ongoing rivalry over certain claims against each other since the time of partition in 1947.

Chaudhary (1999) noted that ethnographic literature reveals that people in the subcontinent regard their neighbours as their kin. A famous saying states: Hamsaya Ma ka jaya, which means 'a neighbour is our mother's son'. The near-neighbours are considered closer than farrelatives (Chaudhary, 1999, p. 17). People in Pakistan tend to transpose their kin relations to other people who they regularly interact with (Lyon, 2004). 'Family' remains the starting reference point to deal with the entire world. Therefore, it is argued, that the people in Pakistan (and subcontinent) perceive other people around them in terms of fathers, brothers, uncles, cousins, nephews etc. (when on good terms), or rival-uncles, rival cousins, rival nephews etc. (when on bad terms). People always use a 'family' lens to categorize other people, using 'labels' to call their neighbours, which are fixed for kin relations: for example, Chacha (father's younger brother) or Taya (father's elder brother) for elderly people; and Beta (son) or Bhatija (nephew) for younger ones.

It can be inferred from the above arguments that how in British India, a familial 'near-ness' was present between Hindu and Muslim neighbours. Logically, the rupture between two groups also developed a familial type of hatred and feud. The dynamics of this conflict can be explained better by using this indigenous conflict model. Psychologically, Pakistan conceptualizes itself in terms of a lineage (Biradari) and perceives other countries as different lineages (Lieven, 2012, p. 12). The India-Pakistan case is a special one, because Pakistanis 
perceive India as an 'other' segment of their own lineage; who wronged them at the time of partition (Batwara). The moralities of Sharike-Bazi' culture of conflict, are therefore reflected in relations between these cousin states.

The psycho-cultural approach lets us to conceptualize Pakistan as a 'wronged' brother in this Sharika rivalry, who remained in a joint family setup with his Indian brothers and cousins for centuries. During the final years of the British raj, he was denied proper representation (or respect) in the future setup of the joint family. He, therefore, demanded a separation and asset distribution. He also developed grievances against his big brother/cousin India over the unfair distribution of assets at the time of partition. The trauma of partition set the future course of action for this 'wronged' and 'wounded' brother who then decided to compete with the Indian brother at any cost. On the other hand, the big brother India felt "dishonoured" and decided to teach a lesson to his "disobedient" younger brother who brought disunity to the family.

\section{The Main Characteristics of Sharike-Bazi}

The following Punjabi proverbs reveal the psychology behind the Sharike-Bazi culture of conflict, which often reflects in Pakistan-India relations.

1. Sharika'n di kandh deg dyo panwy apni majjh thally Aa Jaye

(It is always desirable to bring down the wall of opponents (Shariks) even if your own buffalo dies under its debris).

\section{Sharika'n di kandh pichhy haggan nal ver ni mukdy}

(Only defecating behind the opponents' wall does not settle scores).

Both these proverbs communicate some visible messages: that Shariks are not ordinary enemies but intimate rivals, who should be competed with even at the cost of your own loss. Also, the harm caused to them should be loud and clear, to prove your supremacy. 
'Land' always remains a bone of contention between cousins. There is a saying in Punjab 'as we have no land to divide, we have no reason to quarrel'. The other types of conflicts are also indirectly related to land. Srinivas (1970, p. 44), an Indian anthropologist, describes in detail the conflicts among family members on the division of land and property that result into Sharika rivalry. I have categorized these explanations into numeric (1-8) to highlight the different phases of Sharike-Bazi. The different stages of Sharike-Bazi help us to build an 'analogous model' for analysing different phases of Pakistan-India relations.

(1)'Elders concede that it is better to divide than to quarrel perpetually. (2) Then a second set of quarrels occur - how should the property be divided and who should get what? There are some conventions, but they do not prevent quarrels. (3) After the property, has been divided, one member feels that he has fared badly, and he demands redistribution. (4) In such a case, adjustments are made with some difficulty and the document registered to ensure the similar demands are not made again. (5) Another set of quarrels starts during the paddy transplantation season where the bunds separating the flats are trimmed, and brothers, who are usually neighbours, accuse each other of encroachment. (6) Such disputes go on for years. (7) The partition of property does not promise amity and it is frequently found that adult brothers are not on speaking terms with each other. (8) While members of a lineage show solidarity in relation to lineage, among themselves there are tensions. The narrower the lineage-span, the greater the tension'.

The Sharike-Bazi conflicts start in the life time of elders (usually real brothers), but in the most cases the relationship of mutual respect is maintained (Chaudhary, 1999, p. 51). The bitter quarrels arise between the coming generations of cousins for resettling the distribution over the division of the land etc. There always remain different unpleasant memories on the division of ancestral land and other things (Jaddi Virsa). This division can be readjusted if brothers agree mutually in their life-time. It is not easy to demand a redistribution after a generation's gap.

Another factor contributing to Sharike-Bazi is the 'misuse' of authority and respect by the elder brothers. The brothers having the greater number of sons try to grab the maximum share from the combined resources owing to their numerical strength and physical requirements. It violates the cultural norms in the subcontinent where elder brothers are expected to treat their younger 
siblings with generosity. Therefore, it leads to demands of asset division (Batwara) from the brother having lesser number of sons.

Considering 'Sharike-Bazi' as an analogous model, the above paragraphs explains the mindset behind Sardar Patel's (the first deputy prime minister of India) statement when he conceded to the demand of 'Pakistan' in 1947 by saying that 'it is better to live separately in peace than to live together and quarrel all the time' (Azad, 2014, p. 201). Mr. Jinnah (the founding father of Pakistan) was quite optimistic that 'division' would improve the relations between two nations (Ahmed, 1997). During the famous Gandhi-Jinnah Talks in 1944 to settle the issue of partition, Gandhi (the founding father of India) never agreed to use the term 'nation' for either group and proceeded on the assumption that Hindus and Muslim constitute a 'family' and Muslim family members want to live separately (Wolpert, 1984, p. 231; Singh, 2010). It also implies that had the founding fathers of both nations lived for more years after partition, the higher were the chances for a Pakistan-India rapprochement. As a Sharika rule, the differences which erupted between Jinnah and Gandhi were to be carried over into both nations as a legacy.

Being wronged at the time of partition has always been Pakistani narrative. One Pakistani prime minister, Zulfikar Bhutto, complained about unfair distribution of assets as:

"The British Government could not have done more to tilt the balance of advantage in India's favour.... No attempt was made to provide Pakistan with the minimum requirements for administration, defence, and finance. The country was left to fend for herself. In the maintenance of law and order, the division of assets, military stores, and sterling balances, and even in the transfer of funds, India was given a stranglehold over Pakistan" (Bhutto, 1969, Chapter 18).

It is not surprising, therefore, that Kashmir became an intractable issue between the two 'cousin' or Sharik states. Pakistanis equate Kashmir to Jannat (paradise) and Mr. Jinnah compared it to the jugular vein of Pakistan. Jawaharlal Nehru's (one of the founding fathers of India) attachment to Kashmir can be assessed from his remarks that: 'In the same way that 
Calais was written on Mary's heart, Kashmir is written on mine' (Bolitho, 1954, p. 206).

Therefore, Pakistanis assume Kashmir as their lost 'Jaddi Virsa' (ancestral property).

It implies that the fear of religious annihilation was not the only reason behind the Muslim minority's demand for a separate homeland, but it came directly from being 'neglected' and disrespected in the joint setup. The Agha Khan (the founding father of the Muslim League) narrates how Mr. Gandhi did not treat Muslims in a "fatherly" way during the second Round Table Conference in London to settle the communal issue. It is interesting to recall here that Mr. Gandhi was literally called Bapu (the father) by both Muslims and the Hindus. Agha Khan recollected in his memoir that the Muslims were expecting a father-like affection from Gandhi but were denied:

“.... I opened it by saying to Mahatmaji (Gandhi) that were he now to show himself a real father to India's Muslims, they would respond by helping him, to the utmost of their ability, in his struggle for India's independence. Mahatmaji (the great soul) turned to face me. 'I cannot in truth say', he observed, 'that I have any feelings of paternal love for Muslims. But if you put the matter on ground of political necessity'...." (Singh, 2010, p. 190).

In Sharike-Bazi conflict dynamics, self-esteem and honour (Izzat) is the other major cause of conflict among cousins, which leads to indirect conflicts. It is worth mentioning here that Izzat competition starts after the parting of ways. It remains a joint family asset before separation. After partition, Izzat is divided between parties and therefore much sought after. The following quote explains how 'Izzat' contributes towards the mental construction of local people:

"Every Indian, from the highest to the lowest, has his Izzat, or name to keep. After his son, it is his most cherished possession, and if it is injured he is an unhappy man. And in such a sensitive race there is nothing easier to injure than the Izzat. The injury may be purely imaginary, but it is no less keenly felt.... Moreover, he will neither forget it nor forgive the man who did it" (Walsh, 1929, p. 84). 
An increase in income and land can bring Izzat to someone, but this is only one of many contributing factors (Eglar, 1960, p. 45). There is a saying that 'that the prostitutes have a lot of money, but no Izzat' (Chaudhary, 1999, p. 65). You may lose Izzat without losing wealth or land. It is like the difference between 'standing' and 'honour'. The Izzat is earned by succouring people who expect it from you.

It explains why India lacks the proper status and 'Izzat' in South Asian family because he is incapable of extending the 'desired' amount of care and nurture to other countries in the region; especially Pakistan. Sharika analogy also explains why bad blood developed between Mr. Jinnah and the Congress leaders as he was denied the desired status (Izzat) in the Congress caucus. He literally used the words "it is parting of ways" before going to self-exile in London during the 1930s (Bolitho, 1954, p. 95; Wolpert, 1984). The honour of family is not divided equally between brothers, normally the eldest inherits it. This is how India, by default, took over the seat of 'British India' in all international organizations and Pakistan had to start afresh (Pande, 2011, p. 17).

For this reason, the prestige factor is always taken care of in India-Pakistan relations. Responding to five Indian nuclear tests in 1998, Pakistan conducted six tests (one more) to satisfy herself psychologically, and to prove to the entire world that 'we are no less than India'. At that time, the Pakistani 'civilian' prime-minister could maximise aid and sympathy from the international community, but the public pressure did not let on Pakistan to become "rational". This act was in line with the local idiom "Pagg Uchi ho jaye" (turban must stay high) and implies that Pakistani foreign policy revolves around acquiring prestige from the reference point of India.

In Sharike-Bazi conflict dynamics, the party that manages to grab more resources out of an inherited share and acquires a powerful status (powerful Sharik), starts belittling the other party 
(weaker Sharik). However, weaker parties never acknowledge the standing of their powerful Shariks. They are always engaged in discrediting each other. The resourceful party makes the weaker one feel that he is not even worthy to compete. She boasts in such a manner that the weak party hurts psychologically as it directly attacks her honour (Izzat). The weaker party then resorts to every possible tactic to hurt the stronger party back and regain her prestige. Both Sharik parties sometimes use unlawful tactics to undermine each other. They can join hands with local criminal elements to enhance their strength and use it against their Shariks. The weaker Shariks are always psychologically obsessed that people should not perceive them as 'weak' against their powerful Shariks.

It explains the use of the word 'pygmy' to describe Pakistan by Pandit Nehru when Pakistan went into alliance with the USA in early 1950s (Pande, 2011, p. 94). It also explains the mindset behind using non-state actors by both India and Pakistan to harm each other. In Sharike-Bazi, the powerful Sharik manoeuvres things to deprive his brother/cousin of due shares so that he may not survive and return to the joint setup. It causes more bitterness for the departing party. Field Marshal Auchinleck, the Chief of British Indian Army expressed similar views in October 1948 that the Indian cabinet was determined to undo Pakistan (Burke, 1973, p. 10). It also explains the psychology behind the statements of many Indian leaders soon after Partition, that Pakistan would not survive and would merge back into mother-land India. Pakistan's oftrepeated demand to the international community to be treated on par with India can also be explained from this perspective.

The Sharike-Bazi urges people to make alliances outside their own kin groups and lineages to undermine the power of each other. The alliances in the subcontinent are made with those people with whom one is not in competition (Barth, 1959), which means who are not Shariks. It is also imperative to mention that people in the subcontinent learn that people around them should either obey them or should be obeyed. As the Marathi poet Govindraj puts it that Indian 
society is made up of men "who bow their heads to the kicks from above and who simultaneously give a kick below' (Kakar \& Kakar, 2009, p. 27). Pakistanis are also culturally tuned to form asymmetrical relations with one another (Lyon, 2004, p. 2). Similarly, the Sharik parties tend to be absorbed into these patron-client structures to compete with their enemy cousins. It explains what drove Pakistan to be a part of hegemonic-alliances with the USA (CEATO and SENTO) in 1950s. It was just to compete with India.

There are many other characteristics and dynamics of Sharika rivalry, which are analogous to India-Pakistan relations. The jealousy factor remains very crucial between warring groups and determines their mutual relations. 'Face-saving' remains a hindrance for resolving mutual conflicts between such groups. The empirical evidence for all these characteristics can be found in India-Pakistan relations on one pretext or another.

There is a famous Punjabi saying that "Maaran to drana changa" which means it is better to threaten than kill. The threat of using force is important than actually using force in such relations. The exhibition of weapons is, therefore, a norm in Sharika rivalry, just to threaten the opponents.

Pakistani nuclear build-up can be explained by the logic of "uncertainty about adversary state's intentions" (Mearsheimer, 2014), which also forces state's leaders to behave "rationally" to seek other peaceful means (Sagan \& Waltz, 1995). However, nuclear capability can also tempt small states like Pakistan to take risks against powerful opponents like India (Kapur, 2007, p. 45). Therefore, this is not the only explanation for the Pakistan-India arms-race and their repeated military build-ups, but it can also be explained in terms of an outcome of a specific historical and strategic conflict culture - which shapes the perception of both nations against each other. Psychologically, leaders' in both states try to acquire nuclear supremacy to bolster their own individual popularity (Ganguly, 2002, pp. 127-38). I argue that Pakistani leaders' 
motivation to gain nuclear supremacy against India is owed to a Sharike-Bazi conflict syndrome. Pakistani leaders' intent is to be recognized as "equal" to India by the international family, which is also a popular demand. Hence, the 'threat' of nuclear attack always remains an important factor in their bilateral relations.

\section{The Psycho-Genesis of Pakistan-India Conflict}

As a Pakistani native, I have observed closely that the majority of people in Pakistan hold antiIndian sentiments, stemming from the perception of being 'wronged' and 'cheated' at the time of partition. They are of the view that Pakistan was deprived of its due shares at the time of partition. They also firmly believe that India seized the 'land' of Kashmir by force, and that if provided a chance India would assimilate Pakistan back into its territory. There is a general impression among people that 'Hindus' were not ready to share wealth and power with 'Muslims' in British India, and they did not want Muslims to progress socially and economically. To support their arguments, these people compare their better lives to that of the plight of Indian Muslims.

However, there is also another side of their sentiments. There exists a nostalgia among Pakistani people that the India-Pakistan partition could have been avoided, and they could have managed to live together as one unit. They also repent that opting for a separate state made the lives of left-over Muslims in India so miserable, as they had to face the wrath of the Hindu community. They also long for the harmonious relations between two communities in the past. During partition riots, one can find thousands of examples when people from both sides acted in a "brotherly" way to save the honour of the 'other' community's women (Ahmed, 2012). These mixed feelings of love and hate have been transferred from families to families, and generations to generations. Emotional scenes are seen when someone crosses the border to visit his native place. People on both sides extend warmth and love to such visitors (hundreds of 
such videos are available on youtube.com). There is a rich fictional literature available in terms of poetry, prose and films that explain how an abrupt tide of hatred turned both groups from brothers to sworn enemies.

This paper proposes that Pakistani people possess similar sentiments for Indians as they normally possess for their estranged cousins; the cousins to whom they compete for prestige after family feuds. To the surprise of many Westerners, people in the subcontinent still refer to the India-Pakistan partition as 'Batwara'; a term fixed for the distribution of ancestral property among blood relations. It is more surprising that even after the use of the words 'brothers' and 'family' for Hindus and Muslims by the founding fathers of both nations, several leading political figures, historians and even political scientists, no scholar has ever made a serious attempt to theoretically explore the indigenous 'culture of conflict' to explain India-Pakistan rivalry. This model directly explains how proximity implodes between family members and turns into hate. The analysts have either stressed the syncretic part of Indian culture by following the Muslim poet Iqbal's line, "Religion does not teach mutual enmity" (Kakar, 1996, p. 38), or they have treated both groups along contradictory cultural and religious lines.

The Hindu-Muslim history in the subcontinent is neither all about peace nor is it all about conflict. They have been representing a hybrid history of family like conflict and synthesis in the subcontinent. There is a famous saying in Punjabi language that 'where there are two vessels, they are likely to collide and make a noise' meaning that people in contact, cannot remain without conflict. The Muslims, despite being monotheists, coexisted peacefully with perceived polytheist Hindus. Thanks to large scale conversions from Hinduism to Islam, both communities had similar lineage groups. Obviously, there were religious differences between both groups, but a 'communal' feel remained absent until partition. This was one of the major 
reasons that until the last days of the British Raj, the Muslim majority state of Kashmir was ruled by a Hindu while the Hindu majority state of Hyderabad had a Muslim monarch.

There is always a special characteristic to the enmity for a person who resembles us most but for some reasons we do not accept him as 'us'. Even minor differences between us and them are therefore exaggerated as unbridgeable chasms in what Freud called the "narcissism of minor differences' (Blok, 1998). Unconsciously, people exaggerate their 'minor' differences when there are not many visible differences among them. Such differences can be among brothers, cousins or neighbours; neighbours are the ones whom we can consider as a rival (Kakar, 1996). Interestingly, there is a famous proverb in the subcontinent that grants neighbours the status equal to one's mother's sons (Hamsaya, Maa ka Jaya). Therefore, unconsciously, the enemies like us are offered extra competition by us.

People belong to multiple cultures centred around a wide variety of shared identities, including race, ethnicity, religion, nationality, language, geographical setting, socioeconomic class, profession, gender etc. (LeBaron, 2003, p. 10). Therefore, the often-used variable of 'religion' does not explain the animosity between two groups to its entirety. For being the 'minor' difference among people sharing so many other identities; religion was, therefore, stressed upon by both groups which gave way to generational memories to recall historical antipathy between both groups. This is how religion was to play its role in constructing the future national identity for Pakistanis. Religion had surfaced with much intensity with the departure of the British, because people magnify their internal trivial differences in the absence of any combined threat or enemy as noted by Volkan (1986). Interestingly, the religious history of both groups is also replete with Sharika dynamics. For example, the ancient Indian epic Mahabharata revolves around the war of succession between patrilineal cousins in the 'Great battle of Kurukshetra', while the very first Islamic battle 'Ghazwa-e-Badr' against infidels, was also between fraternal cousins. 
Both groups never emphasised 'religion' against their colonial masters or started any holy war. Ideally, the Hindus should have hated the (Christian) British equally for being invaders and imperialists like Muslims. Beef-eating was also common between both; a practice much hated by Hindus. However, religious hatred never exploded between Hindus and British outsiders as they remained strangers, not becoming 'familiar' as Muslims did, thus, acquiring the status of 'other' (Kakar, 1996, p. 22).

The British never became a part of the Indian family as Muslims did, because Hindus and Muslims lived side by side for more than a millennium and shared daily life. A psychological feeling of near-ness had developed between the two communities. India was the place where the lives of different communities were intertwined in love and hate, due to proximity, not distance. Therefore, nearness, rather than distance, is more to do with the venom in ethnic and religious violence in South Asia (Nandy, 2001). It provides rationale to investigate the Pakistan-India conflict by situating it in the same cultural world and using family conflict dynamics.

As William Blake said: "it is easier to forgive an enemy than to forgive a friend". A few verses by a Punjabi-Pakistani poet Ustad Damen are quoted here to seek insight into the India-Pakistan problem. He had travelled to India after partition and recited this poem in a seminar. The audience, including prime-minister Nehru, burst into tears after hearing these verses.

We may not say it but know it well

You lost your way. We too.

Partition has destroyed us friends.

You too, and us.

The wakeful have quite plundered us.

You slept the while, and we.

Into the jaws of death alive

You were flung. We too.

Life still may stir in us again:

You are stunned yet, and we. 
The redness of the eyes betrays

You too have wept, and we. ${ }^{b}$

Another of Damen's verses explains Pakistan India partition in these words:

A strange divide has ensued to Pakistan; It has been cut into two sides / halves (Partition of India and Pakistan).

How can surgeons cure Pakistan; while 'ointment' is in this side, and 'wound' is in other side.

How can we reach at destination; while 'horse' is in this side, and 'cart is in other side. $^{c}$

The roots of Pakistan's rivalry with India lie in how Pakistan emerged as a nation out of colonial India. The India-Pakistan Sharika-dyad cannot be explained without mentioning the Jinnah-Gandhi-Nehru triad, who are unequivocal founding fathers of both nations. The antagonistic relationship among these three titans had far reaching results in locking their followers (ideological sons) in 'ever-red' rivalry. Even after the seventy years of partition, more than one billion people in the subcontinent are still engaged in a debate about who the villain responsible for the 'Batwara' of British India was. Naturally, people in both countries blame the 'other' father of nation for this partition.

It is widely believed that partition and communal riots could have been avoided if these father figures had overcome their mutual differences. The masses were politically illiterate in those times and they just followed their beloved leaders blindly. People in the subcontinent are psycho-culturally tuned to take their political leaders or any institutional head as their own father. The metaphors of kin relations are, therefore, used for political leaders in the subcontinent.

India-Pakistan rivalry can also be explained as the legacy of hostility between Indian National Congress, and the Muslim League led by Jinnah. Jinnah had to leave the former party because he was not accommodated properly and was dubbed as "spoilt child" by senior Congress 
leaders (Bolitho, 1954, p. 94). Both parties, therefore, developed incompatible views regarding the future of India after the departure of the British. It set the path for post-1947 relations between two states (McLoed, 2008, p. 1). From the outside, it resembles nothing so much as a family feud - and psychologically speaking, it's a very apt analogy.

Although, the Muslim demand for separate homeland can be explained as their desire for regaining 'power' they had enjoyed for centuries during their imperial rule over India. However, the rupture between two communities can also be traced as to how the Congress party dealt with the Muslim League during the last years of the British raj. As partition neared, the Muslims began to feel that their reservations were not properly considered, and their demands were thus not met. The Muslim League was ignored and humiliated after Congress's victory in 1937 which set the path for Pakistan (Khaliquzzaman, 1961). The Muslims, suddenly the 'junior' family members, felt neglected - and as younger siblings oftentimes do, they became extra-competitive. It had created a sense of 'not mattering at all' among the Muslim minority who naturally wished 'parity' with their Hindu counterparts. Such combative feelings remained dormant within both groups in the past because minority Muslims were the rulers themselves, whereas the majority Hindus were also well accommodated in state apparatus owing to their obvious numeric strength.

The Hindu-Muslim communal divide began to widen with the increasing differences between the founding fathers. Gandhi's role can be considered as of a weak 'father' or elder brother who struggled in vain to keep the integrity of family. He could neither convince Jinnah nor Nehru to keep the family united. Both were strong contenders to family headship. During the last days of the Raj, Gandhi had proposed to the last British viceroy to appoint Jinnah as the future premier so that the unity of India may be restored. But to his own dismay, Jawaharlal did not agree to this proposal. The mutual differences between Jinnah and Nehru remained a major factor in India's vivisection (Singh, 2010, p. 502). 
Viewed this way, the India-Pakistan conflict owes more to historical and psychological "nearness" than to mere competition for resources or territory. And that much is clear in the language they use to talk about each other. For example, in many parts of the subcontinent, especially in both Punjabs, the word used for the 1947 partition is 'Batwara', which literally means "the distribution of ancestral land" between brothers or patrilineal cousins. The word comes with resonances that the alternate English word "partition" simply does not carry: harmonious family; painful division; cousin rivalry; love-hate competition. The usage of this word "Batwara" substantiates the assumption that Sharike-Bazi conflict dynamics are present in India-Pakistan conflict. The political elite from both sides appear to compete with each other like patrilineal cousins, and always struggle to move the legacy of their national fathers forward.

Interestingly, India has always used the metaphor of the south Asian family. Owing to her geographical, demographic, and economic supremacy; India claims the 'big brother' role in the south Asian family, which is denied by Pakistan on the pretext that India had failed to fulfil the cultural expectations associated with this role. As a cultural rule, elder brothers are expected to be tolerant and generous. But India's policy towards Pakistan proved to be the acme of power politics, which nourished the most truculent instincts in Pakistan's psychology and political culture (Malik, 1993). Therefore, since partition, India's leading role in South Asia is persistently challenged by Pakistan (Buzan \& Rizvi, 1986).

After partition, the future course of the Pakistani state was determined by certain psychological constructs: feeling of being 'wronged' at the time of partition, and the desire of competing with Indians at any cost. These psychological constructs can be traced in Sharika conflict dynamics. This was the setting stage for Pakistanis as a nation state. These psychological constructs led Pakistan's nascent state to adopt religion as a path, and the army as its saviour. As Pakistani military president Zia once said: 
'Turkey or Egypt, if they stop being aggressively Muslim, they will remain exactly what they are.... But if Pakistan does not become and remain aggressively Islamic it will become India again.... swamped by this all enveloping embrace of India' (Singh, 2010, p. 497).

Interestingly, it was not a military, but a civilian prime minister, Bhutto, who talked about “eating grass for getting nuclear bomb" (Khan, 2012, p. 135) after 1971 defeat; and, declared a 1000-year war against Indians in UN general assembly (Wolpert, 1993). He refused the international community's advice to become realistic and accept Indian regional supremacy, by firmly demanding "equitable" settlement for "honourable" peace (Bhutto, 1969, Chapter 18). He became popular after running a hate-campaign against Ayub (a military dictator) for signing the Tashkent ceasefire accord with India to end the 1965 war. He had emerged as the uncontested civilian leader from west Pakistan, for having an aggressive anti-Indian stance.

Therefore, it is inadequate to say that only the army pursues aggressive policies against India for their bureaucratic ends. This bitter competitive urge is an outcome of interactive process between masses and political elite, which drives Pakistani leaders, army officers and populace to defy India's obvious demographic, economic and military supremacy. It results from certain moral views created by indigenous conflict culture. It is always desirable that your country should have the capacity to defend itself but believing that your country can/should defeat a country ten times larger than your own can be better explained through a psycho-cultural analysis.

It is also worth mentioning that the India-Pakistan relationship is not always an equation of hate-hate, but it has been a combination of love and hate, and both states have responded cooperatively to a few possibly contentious issues, such as 'water-sharing'. Both rivals have been successful to find some solutions, if the element of "prestige" was not involved (Malik, 1993). 


\section{The Significance of Sharike-Bazi Conflict Theory}

This paper has presented the Sharike-Bazi conflict model as an exploratory theory to analyse India-Pakistan emotion-laden and asymmetric rivalry, which is a persistent challenge to regional security in the Asian sub-continent. The study of indigenous 'culture of conflict' enables us to peek into peoples' indigenous conflict behaviour and to use them as an 'analogy' in the context of nation-states, which are said to be wrapped in several institutional and bureaucratic layers. Arguably, preindustrial societies and modern-day nation-states differ in many ways but none of these suggest obvious reasons why the dynamics of conflict would not be similar in each (Ross, 1993, p. 152).

Pakistan and India can be related as two 'parted' segments of a family (or lineage) as Lieven (2012) has observed that Pakistanis perceive themselves in terms of a lineage group in world community. The conflict between the two had led the both communities to end up in rival nation-states. Sharike-Bazi conflict theory takes people and their conflict behaviour as units of analysis. The better way to understand a state's action is to analyse the most influential social institutions/actors in society. In the Pakistan-India case, these are kinship institutions that create certain moral views regarding emotions, conflict-perception, anger, friendship, enmity etc. in its people.

The fateful factor of prestige (Izzat) in Sharike-Bazi theory is not supported by the realists. To them, the ultimate 'end' of a state is 'power' and policy makers try to attain power to maximize their relative power in the international system. The 'States pursue the policy of imperialism by acquiring more power' (Morgenthau, 1985, p.62). However, for Pakistan, the pursuit of power seems to aim at maximising its "prestige" against India, and to prove to the international community that 'Look! Pakistan has 'survived' against all odds; we deserve to be treated on par with India". The explanation for Pakistan's behaviour can be drawn from Weber (1994) 
who defined 'honour' and 'prestige' as important variables in interstate relations. Power is a mean to an end, not an end in itself; therefore, any theory about politics must be rooted in some understanding of those “ends" (Max Weber cited in Lebow, 2008, p.22).

The Sharike-Bazi theory is related to the 'character' and 'behaviour' of a state; how states can exhibit the attributes of its people's behaviour and psyche. It explains how Pakistani state's institutions, sometimes, reflect human character. Lebow (2008) notes that states formulate policies based on the need for self-esteem and people seek self-esteem not only through personal activities, but through the social units to which they are attached, such as sports teams and nations. It explains why Pakistan-India cricket matches are always termed as 'cricketrivalry' by international commentators for their emotional spirit. Although, the 'spirit' is purely a human drive; organizations and states do not have psyche and cannot be treated as persons, but they can respond to the needs of spirit in the same manner as they do to the material needs of their citizens (Lebow, 2008). These observations support the argument made in this paper that it is Sharike-Bazi 'psyche' and 'spirit' that has been institutionalized by both states especially by Pakistan for being the weaker player.

Sharike-Bazi theory explains "rationality" as a learned cultural concept, which might challenge the realist notion of rationality based upon material interests. Structural theorists find rationality in the state, whereas, social psychologists identify rationality within the motives, goals, emotions, and cognition of individual actors (Weingarten, 1993, p. 187). The paper has argued that it is family dynamics, informed by their 'culture', that shape Pakistani actors' "rationality" for interpreting actions and motives, which serve the same explanatory role for them as 'material interests' do for realists.

Owing to their conflict prone character, India-Pakistan relations and their long-standing conflicts have been discussed mostly by using realist paradigms which do not offer holistic 
understanding of their conflict dynamics. It is not to say that rational/material theories are not explanatory; but they are incomplete in the Pakistan-India case. For example, for realists, there is no cultural, ideological, religious or historical enmity between India and Pakistan (McLeod, 2008, p.10). However, such ideational factors provide both states with suitable "rationality" (Vasquez, 2005).

I, therefore, argue that Sharike-Bazi conflict theory makes an ideational alliance with Constructivism, which can offer a more complete and substantive understanding of PakistanIndia conflict as Chatterjee (2008) has noted. The paper has examined in detail why and how actors adopt certain conflict behaviour, which stems from their socially accrued values from the institution of family. This conflict behaviour when extrapolated to the level of state policymaking provides the actors with a "rationale" while assessing the suitability of certain options for action. It is in line with the Constructivist "logic of appropriateness" (Reus-Smit, 2009 , p. 221) that actors' choices are also based upon specific rule-guided behaviour and identity, not always upon cost-benefit analysis.

Wendt's famous illustration '500 British nuclear weapons are less threatening to the United States than 5 North Korean nuclear weapons' (Wendt, 1995, p. 73) can explain that "perception” makes Pakistan feel threatened by India's nuclear weapons, and vice versa. Simply put, if people and the political elite of a state perceive some other state as hostile, they would prepare for wars, expect wars, and will fight wars, and vice versa. However, the State remains the principal unit of analysis for Constructivists; state identity is constituted by state practices where peoples' and policy makers' ideas, beliefs, and perception about other states is a crucial factor (Wendt, 1999, pp. 215-24).

It can be argued therefore that origins and practices that produce and reproduce state identity are not explained well in Constructivism and are said to emerge from the interactions between 
states as Larson (2012) has observed. However, Sharika theory spells out that Pakistani state identity is the outcome of an interactive process between actors' individual psychology and their larger socio-political institutions. It also helps the Constructivists in finding the cultural roots of how Pakistani actors' psychology and conflict perception is shaped by their indigenous family dynamics.

This paper has examined that the earliest learning experience of 'authority and governance' by Pakistanis is acquired from the institution of the family, therefore, people desire that their nations/states should function in terms of their idealized family models. Peoples' beliefs about ideal family life serves as a conceptual anchor for their larger moral belief systems and dictate their political attitudes about how society and nation should function (Lakoff \& Johnson, 1980). Such metaphorical understanding of the nation-as-family directly informs peoples' political worldview; 'Directly, but not consciously' (Lakoff, 1996). To that end, prevailing family models in any society - joint-family in Pakistan - produce certain moral systems, which influence the actors' perception about governing a nation, and, functionality of the state. The mechanism of linking family dynamics to the state's actions is a "conceptual metaphor" that actors use to reason about abstract concepts in the form of more concrete, daily-based knowledge. These metaphors are automatically acquired based on every-day experiences, primarily at the early stages of life when basic neural patterns are being formed and strengthened in the mind (Lakoff \& Johnson, 1980). They set up parallels between difficult and easy concepts, especially between family dynamics and functioning of the state (Lakoff, 1999).

Similarly, interstate conflict is a highly abstract concept, therefore, it is conceptualized in simpler terms and concrete conflict dealing concepts observed in the family domain. Pakistani people as well as political actors use the dynamics of their family conflicts to reason about their interstate conflicts, especially with the nation to whom they share a number of commonalities 
ranging from geographic proximity to identical kinship structures. It is appropriate to mention here that the nation, state, politics, governance, group conflict etc. being in the highly abstract domains of cognition, have always been reasoned by using conceptual metaphors in international relations by the theorists (Lakoff, 1999), for example, states as "animals" possessing survival instinct.

As the 'relations between nations are not essentially different from the relations between individuals' (Morgenthau, 1946, p. 43), therefore, to understand the whole, one must know the parts. The interstate relations are relations between individuals on wider scale. Therefore, this paper has examined the individual's behaviour to better understand Pakistan's behaviour. Similarly, the dynamics of the institution of family in Pakistan have been explored to explicate the state's propensities towards taking certain actions, since, to paraphrase Reich (1970, p. 30) that 'state' after all is a large family. States are hierarchically organized groups of people - full of emotions, and, national interest is the highest level of social as well as psychological aggregation. Therefore, states cannot ignore popular sentiments regarding aggression while formulating their policies (Lebow, 2008). The state's actions mostly depend upon the perception of situation conceptualized by the individual actors responsible for decisionmaking, which, in turn, is heavily influenced by their indigenous family dynamics in PakistanIndia case.

Sharika theory has used a 'bottom-up' approach to systematically analyse psycho-cultural, cognitive, and emotional propensities that shape actors' ideology, belief, perception, and policy-making, and, thus, determine the state's actions and behaviour. It is imperative to mention here that Sharika conflict theory explains conflict behaviour not as an individual's belief but as a socially constructed set of ideas about dealing with conflict, developed within the ideal family model in Pakistan (and India). As Wendt (1992, p. 398) too has pointed out: it 
is not individual perceptions, but social structures - or system of the intersubjective norms, ideas, beliefs and values that construct identities - and in turn shapes the interests of the actors.

The conflict theory developed in this paper enables us to conceptualize Pakistan and India as estranged cousins (Shariks), and thus throws light on the manners in which they have been handling their relationships after partition. It provides us with an additional reference point to explain Pakistan's competitive policies against India. Pakistan always starts from India as its central reference point to deal with entire international community. The Sharika theory has the potential of applicability to all neighbour states which have culturally similar groups, and who were once part of a single society, for example Pakistan-India-Bangladesh, Pashtuns in Pakistan and Afghanistan, North-South Korea, Serbia-Croatia-Bosnia etc.

\section{Conclusion}

This paper has examined the Pakistan-India partition and their ongoing conflicts from a psychocultural perspective. It provides a theoretical model to compare peoples' family level conflict behaviour to that of national behaviour. The kinship institutions are the most pervasive and commanding institutions in both countries, which play a central role in constructing peoples' worldview and conflict behaviour. The paper explains how these conflict behaviours create certain moral views effecting peoples' political behaviour and perception, which is reflected in inter-state relations between India and Pakistan. Therefore, after living together for more than a millennium both nations have been locked into an intimate rivalry following their indigenous conflict behaviour.

The paper has also examined that people in the subcontinent start from the reference point of the 'joint-family' to interpret the entire outside world in terms of their kin relations. From granting the status of 'spiritual father' to their teachers, 'family-head' to bosses, and 'fathers' 
to political leaders, people in the subcontinent keep on transposing the psycho-cultural moralities of kinship-relations into every other institution. Similarly, they also frame their enemies in terms of kin rivals. The moralities of conflict dealing learned within their fateful kinship institutions are transmuted to other institutions of the state which are said to be responsible for policy making

India and Pakistan can be termed as 'patient' states suffering from deep-seated trauma of 'separation' from each other. They are prisoners of 'I am not respected' and 'I am wronged' syndromes respectively. This paper has examined that the collective hysteria existing in both nations to hate and compete with each other has cultural origins, characteristics and mechanisms (or 'operating system) emanating from their indigenous culture of conflict at the family level. The social institutions, cultural concepts, and cultural artefacts remain in dialectic relationship to form the origins and characteristics of multiple psychological phenomena such as emotions, maternal love, sexuality, memory, reasoning, anger, perception, development process, love or hatred for any country, and mental illness etc. (Ratner, 2012).

Pakistan denies India's big-brother role in south Asia because India has not extended proper care and nurturance to Pakistan. The conflict between both nations owes more to their cultural and historical near-ness and same-ness than their differences. Their rivalry can be best understood as: 'the people who are like us are always extra competitive with us'. The IndiaPakistan rivalry is of familial nature for being lived side by side for centuries, and, because neighbours in the subcontinent are also taken as kin. Despite religious differences both groups share many cultural similarities. But it is also true that the most brutal clashes are always among the culturally similar groups.

If we study Pakistani people and its political elite's behaviour towards India or vice versa, there is striking similarity on both sides which exhibit Sharike-Bazi spirit. This paper proposes that 
Pakistan's policies against India are not based upon cost-benefit analysis, but their 'rationality' is guided by their specific culture of conflict. It can explain Pakistani intense competitive drive against India, which determines the path for policy makers to use every method to defy Indian obvious numerical supremacy. The preservation of prestige and honour against India always remains the foremost foreign policy goal for Pakistan. Its huge risks over strategically unimportant targets against India, on-and-off use of limited military force, and, the acquisition of nuclear capability by a much weaker state like Pakistan can also be explained through Sharike-Bazi spirit. It is due to this spirit that Pakistanis believe that their one soldier is equal to ten Indian soldiers.

Acknowledgement: I am indebted to my parents Ch. Abdul Kadir, Kaneez Fatima \& Fahmeeda Asmat for introducing me to the psychology of Punjabi culture.

\section{End Notes:}

\footnotetext{
a By Biradari (literally brotherhood), I do not mean caste-system or Varna (literally, 'colour') in Hinduism; the four sweeping social/traditional categories i.e. Brahmin, Ksatryia, Vaisya, and Sudra, but it is more akin to the Hindu institution of Jati. The institution of Biradari or Jati is second only to the extended family as a pervasive social dimensions of identity; a group of families with a common descendant.

b https://uddari.wordpress.com/2017/03/25/punjabi-poetry-ustad-daman/, Translated by F. Sharma

${ }^{c}$ Translated by the author from Punjabi language
} 


\section{REFERENCES}

Ahmed, A. (1997). Jinnah, Pakistan and Islamic identity: The search for Saladin. London; New York: Routledge.

Ahmed, I. (2012). The Punjab bloodied, partitioned and cleansed: Unravelling the 1947 tragedy through secret British reports and first-person accounts. Karachi: Oxford University Press.

Ahmed, I. (2013). Pakistan the garrison state: origins, evolution, consequences, 1947-2011. Karachi: Oxford University Press.

Azad, A. (2014). India wins freedom: Complete Version. New Delhi: Orient Blackswan Private Limited.

Aziz, K. K. (1993). The murder of history: A critique of history textbooks used in Pakistan. Lahore: Vanguard.

Bar-Tal, D. (2013). Intractable conflicts: Socio-psychological foundations and dynamics. Cambridge University Press.

Barth, F. (1959). Political leadership among Swat Pathans. London School of Economics. Monographs on Social Anthropology, No. 19.)[viii], 143. London: University of London, The Athlone Press.

Bhutto, Z. A. (1969). The myth of independence. London: Oxford University Press.

Blok, A. (1998). The narcissism of minor differences. European Journal of Social Theory, 1(1), 33-56.

Bolitho, H. (1954). Jinnah: Creator of Pakistan. Karachi: Oxford University Press.

Brass, P. (1974). Language, religion and politics in India. London: Cambridge University Press.

Burke, S. (1973). Pakistan's foreign policy; an historical analysis. London: Oxford University Press.

Buzan, B. (1991). People, States \& Fear: An agenda for international security studies in the post-cold war era. New York: Harvester Wheatsheaf.

Buzan, B., \& Rizvi, G. (1986). The Future of the South Asian Security Complex. In South Asian Insecurity and the Great Powers (pp. 235-252). Palgrave Macmillan, London.

Channabasavanna, S. M., \& Bhatti, R. S. (1982). A study of interactional patterns and family typologies in families of mental patients. Readings in transcultural psychiatry, 149-161.

Chatterjee, S. (2008). Intra-State/Inter-State Conflicts in South Asia. In N. C. Behera (Ed.), International Relations in South Asia: Search for an Alternative Paradigm (pp. 177-208). SAGE Publications India.

Chaudhary, M. A. (1999). Justice in practice: legal ethnography of a Pakistani Punjabi village. Oxford University Press, USA.

Cohen, S. P. (2013). Shooting for a century: the India-Pakistan conundrum. Brookings Institution Press.

Cole, M. (1998). Cultural psychology: A once and future discipline. Harvard University Press.

Eglar, Z. S. (1960). A Punjabi village in Pakistan. New York: Columbia University Press.

Fair, C. C. (2014). Fighting to the End: The Pakistan Army's Way of War. Oxford University Press.

Faruqui, A. (2003). Rethinking the National Security of Pakistan: The Price of Strategic Myopia. Ashgate Pub Limited.

Ganguly, S. (2002). Conflict unending : India-Pakistan tensions since 1947. Columbia University Press.

Ganguly, S. (2016). Deadly Impasse: Indo-Pakistani Relations at the Dawn of a New Century. Cambridge: Cambridge University Press.

Gautier, F. (1996). Rewriting Indian History. New Delhi, Vikas Publishing.

Kakar, S. (1996). The colors of violence: Cultural identities, religion, and conflict. University of Chicago Press.

Kakar, S. (2006). Culture and psychoanalysis: a personal journey. Social Analysis, 50(2), 25-44. 
Kakar, S., \& Kakar, K. (2009). The Indians: Portrait of a people. Penguin Books India.

Kapur, S. P. (2007). Dangerous deterrent: Nuclear weapons proliferation and conflict in South Asia. Stanford University Press.

Khaliquzzaman, C. (1961). Pathway to Pakistan. Lahore: Longmans, Pakistan Branch.

Khan, F. H. (2012). Eating Grass, The Making Of The Pakistani Bomb. Stanford University Press.

Lakoff, G. (1996). Moral politics: What conservatives know that liberals don't. University of Chicago Press.

Lakoff, G. (1999). Metaphorical Thought in Foreign Policy: Why Strategic Framing Matters To the Global Interdependence Initiative.

Lakoff, G., \& Johnson, Mark. (1980). Metaphors we live by. Chicago: University of Chicago Press.

Lancaster S. (2015). Metaphors that Move Minds. In Winning Mind (pp. 41-67). Palgrave Macmillan, London. Retrieved from https://doi.org/10.1057/9781137465948_3

Larson, D. (2012). How Identities Form and Change: Supplementing Constructivism with Social Psychology. In V. Shannon \& P. Kowert (Eds.), Psychology and Constructivism in International Relations: An Ideational Alliance (pp. 57-75). Ann Arbor: University of Michigan Press.

LeBaron, M. (2003). Bridging cultural conflicts: A new approach for a changing world. San Francisco: JosseyBass.

LeBaron, M., \& Pillay, Venashri. (2006). Conflict across cultures: A unique experience of bridging differences. Boston, Massachusetts, London: Intercultural Press.

Lebow, R. N. (2008). A cultural theory of international relations. Cambridge University Press.

Lieven, A. (2012). Pakistan: A hard country. London: Public Affairs.

Lyon, S. M. (2004). An anthropological analysis of local politics and patronage in a Pakistani village. Edwin Mellen Press.

Malik, H. (1993). Dilemmas of national security and cooperation in India and Pakistan. London: MacMillan Press Springer.

McLeod, D. (2008). India and Pakistan : Friends, rivals or enemies? Aldershot; Burlington, VT: Ashgate.

Mearsheimer, J. (2014). The tragedy of great power politics. New York, WW Norton \& Co.

Morgenthau H. (1985). Politics Among Nations, revised by Kenneth W. Thompson. $4^{\text {th }}$ ed. New York: Knopf.

Morgenthau, H. (1946). Scientific man vs. power politics. Chicago, IL: University of Chicago press.

Morlidge, S., \& Player, S. (2010). Future ready: How to master business forecasting. John Wiley \& Sons.

Nandy, A. (2001). Time warps: The insistent politics of silent and evasive pasts. Orient Blackswan.

Nandy, A., Trivedy, S., Mayaram, S., \& Yagnik, A. (1995). Creating a nationality: The Ramjanmabhumi movement and fear of the self. New Delhi: Oxford University Press.

O'Connor, T. J. (1971). A methodology for analogies. Technological Forecasting and Social Change, 2(3-4), 289-309.

Pande, A. (2011). Explaining Pakistan's foreign policy: escaping India. Milton Park: Routledge, Taylor \& Francis.

Pandey, G. (1990). The Colonial Construction of Communalism in North India. Delhi: Oxford University Press.

Paul, T. V. (2014). The warrior state: Pakistan in the contemporary world. Oxford University Press.

Paul, T. V. (Ed.). (2005). The India-Pakistan conflict: an enduring rivalry. Cambridge University Press. 
Ratner, C. (2012). Macro-Cultural Psychology. In Valsiner, J.( Ed.), The Oxford handbook of culture and psychology (pp. 207-240). Oxford University Press.

Razvi, M. (1982). Pakistan's geopolitical environment and security. Pakistan Horizon, 35(3), 29-43.

Reich, W. (1970). The mass psychology of fascism. New York: Farrar, Straus \& Giroux.

Reus-Smit, C. (2009). Constructivism. In S. Burchill, A. Linklater, R. Devetak, J. Donnelly, M. Peterson, \& J. True (Eds.), Theories of International Relations (pp. 212-236). Palgrave Macmillan.

Rizvi, H. (1993). Pakistan and the geostrategic environment: a study of foreign policy. Palgrave Macmillan, UK.

Robinson, F. (1974). Separatism among Indian Muslims: The politics of the United Provinces' Muslims, 18601923. London: Cambridge University Press.

Ross, M. H. (1993). The culture of conflict: Interpretations and interests in comparative perspective. Yale University Press.

Ross, M. H. (1995). Psychocultural interpretation theory and peacemaking in ethnic conflicts. Political Psychology, 523-544.

Ross, M. H. (Ed.). (2009). Culture and belonging in divided societies: Contestation and symbolic landscapes. University of Pennsylvania Press.

Rubin, J. Z., Pruitt, D. G., \& Kim, S. H. (1994). Social conflict: Escalation, stalemate, and settlement. New York: McGraw-Hill Book Company.

Sagan, S., \& Waltz, K. N. (1995). The spread of nuclear weapons : A debate(1st ed.). New York: W.W. Norton.

Savarkar, V. D. (1969). Hindutva; who is a Hindu?. Veer Savarkar Prakashan.

Sayeed, K. B. (1960). Pakistan: The Formative Phase. Pakistan Publishing House.

Siddiqa, A. (2007). Military Inc, The politics of Military's Economy in Pakistan. Washington: Woodrow Wilson Centre for International Scholars.

Singh, J. (2010). Jinnah : India, partition, independence. Karachi ; Oxford University Press.

Srinivas, M. (1970). Caste in modern India, and other essays. London: Asia Pub. House.

Stoddart, C., \& Hession, C. H. (1951). The Psychocultural Approach to Social Science. The Journal of Higher Education, 22(6), 310-344.

Syed, A. H. (1982). Pakistan: Islam, politics, and national solidarity. Praeger Publishers.

Talbot, I. (2003). Back to the future? Pakistan, history and nation building. In C.H. Kennedy (Ed.), Pakistan at the Millennium (pp. 65-95). Karachi: Oxford University Press.

Vasquez, J. A. (2005). The India-Pakistan conflict in light of general theories of war, rivalry, and deterrence. In T.V. Paul (Ed.), The India-Pakistan Conflict: An Enduring Rivalry (pp. 54-79). Cambridge University Press.

Volkan, V. D. (1986). The narcissism of minor differences in the psychological gap between opposing nations. Psychoanalytic Inquiry, 6(2), 175-191.

Walsh, C. H. (1929). Indian village crimes: with an introduction on police investigation and confessions. Ernest Benn Limited.

Waltz, K. (1979). Theory of international politics. New York: McGraw Hills.

Weber, M. (1994). The profession and vocation of politics. Weber: political writings (pp. 309-69). Cambridge University Press.

Weingarten, H. R. (1993). International Conflict and the Individual: Or," what Drives that Person with Whom I Have to Negotiate and Can Understanding His Motivation Really Help?". In W. Zimmerman, \& H. K. Jacobson (Eds.), Behavior, culture, and conflict in world politics (pp. 177-196). University of Michigan Press. 
Wendt, A. (1992). Anarchy is what states make of it: the social construction of power politics. International organization, 46(2), 391-425.

Wendt, A. (1995). Constructing International Politics. International Security, 20(1), 71-81.

Wendt, A. (1999). Social theory of international politics. Cambridge University Press.

Wolpert, S. A. (1984) Jinnah of Pakistan. New York: Oxford University Press.

Wolpert, S. A. (1993). Zulfi Bhutto of Pakistan: His life and times. New York: Oxford University Press. 